\title{
Will Budapest be a climate-resilient city? - Adaptation and mitigation challenges and opportunities in development plans of Budapest
}

\author{
By Attila Buzási ${ }^{1}$
}

\begin{abstract}
Cities are responsible for more than two thirds of global greenhouse gas emissions, moreover, they consume the majority of resources and account for a great proportion of globally generated waste. Due to the concentration of the population, of economic activities, of consumption and emissions, cities play a crucial role in the abatement of the negative effects of climate change. Consequently, adaptation and mitigation actions in urban areas are greatly important regarding the decrease of urban vulnerability and fostering urban climate change resilience. Since approximately $20 \%$ of the Hungarian population lives in Budapest, moreover $40 \%$ of the Hungarian GDP is generated here, the capital city is the hub of consumption; or, in other words, it is the largest contributor of greenhouse gas emissions. There is growing interest in resilience-based studies not only at the international scale, but also in Hungary. Nevertheless, there are only a few Hungarian studies with respect to urban adaptation and mitigation strategies, and moreover, to related issues such as reduction of climate exposure or urban vulnerability. The aim of this research paper is to analyse adaptation and mitigation actions in different development and management plans of Budapest, and to identify the main challenges and opportunities considering adaptation to climate change in order to Budapest will be able to become a climate-resilient city.
\end{abstract}

Keywords: climate change, Budapest, mitigation, adaptation

\section{Introduction}

The United Nations released the publication World Urbanization Prospects: The 2009 Revision in 2010 (UN, 2010). The key findings of this revision concerned the number of people living in urban areas, which, for the first time in the history of humankind, had exceed the number of people living in rural areas. Thus, the world has become more urban than rural since 2009. Moreover, according to the 2011 revision (UN, 2012) the percentage of urban population will likely reach $60 \%$ by 2030 and slightly less than $70 \%$ by 2050 . Furthermore, $72 \%$ of the European population lives in cities (Han et al., 2012) and the permanent urbanisation can have negative impacts not only from an ecological, but also from a social and economic aspect too. Whereas cities house the majority of the world's population, urban areas occupy less than two percent of the Earth's land surface (Walsh et al., 2011), thus cities seem greatly concentrated areas 
considering the population. According to several studies (LeQuere et al. 2009; O'Meara, 1999; Dhakal, 2010; International Energy Agency, 2008) cities are responsible for more than two thirds of global greenhouse gas emissions, and they consume the majority of resources and account for a great proportion of globally generated waste. From an economic aspect, cities concentrate a disproportionate amount of the world's economy and headquarters of firms, since they are the centres of knowledge and innovation and provide economies of scale and efficiency benefits (McKinsey Global Institute, 2011). Due to the concentration of population, of economic activities, of consumption and emissions, cities play a crucial role in the abatement of negative effects of climate change (Grimm et al., 2008).

Considering the above, climate-related urban research should focus on adaptation and mitigation actions regarding the decrease of urban vulnerability and fostering urban climate change resilience. Nowadays, one of the main issues concerns the hows and whys of integrating adaptation and mitigation actions into urban policies, whilst considering the possible impacts and risks associated with climate change. Climate resilience is increasingly becoming a priority for local policy action, especially focusing on adaptation and mitigation (Csete \& Horváth, 2012).

There is growing interest in resilience-based studies not only at the international scale but also in Hungary (Csete et al, 2013). The second edition of the National Climate Change Strategy, which contains the National Adaptation Strategy that highlights sustainability as a basic element of the practical implementation on settlement level, is due to be published later in 2014. This strategic document dedicates an entire chapter to adaptation goals and actions considering our built-up environment. Nevertheless, there are only a few Hungarian studies dealing with urban adaptation and mitigation strategies and other related issues, such as the reduction of climate exposure or urban vulnerability.

This study is focusing on the climate-related actions in the various development and management plans of Budapest outlined in recent years. Adaptation and mitigation efforts and actions in these plans indirectly identify the main climate challenges facing the Hungarian capital, whilst providing short and long-term solutions to be able to cope with them. In the second and third section of this study, the main characteristics of Budapest are noted, and the foreseeable changes in climate patterns are identified, thus the main challenges can then be described. In the fourth section, divergent actions in the development and management plans of Budapest are examined from the aspect of climate mitigation and adaptation. The main goal is to determine whether these plans include climate-related actions and whether these efforts are in line with local challenges. In the fifth section, a summary and conclusions are presented to establish whether Budapest will be able to cope with climate related challenges with explicit mitigation and adaptation efforts or whether a lack of appropriate strategies and actions characterise the city's future.

\section{Study area}

Budapest, capital of Hungary is situated along the river Danube in the Carpathian basin. It has a population of 1.7 million -about $16-17 \%$ of the country's population -, its area is $525 \mathrm{~km}^{2}$, the population density is 3379 capita per $\mathrm{km}^{2}$ 
(Hungarian Central Statistical Office, 2012). The population decreased steadily by 2007, but nowadays this decline has stopped, as the number of people moving into Budapest exceeds the number moving away from the city. International immigration plays a crucial role in demographic trends, because it can compensate the natural decline.

The ratio of built-up area is 52\%, (Budapest 2030 - Long-term City Development Concept, 2013) but according to the Landscape Management Plan, this figure may well reach $60 \%$ in the near future. From a climatic point of view, the intensity of green covered areas is a significant indicator, which is approximately $5 \mathrm{~m}^{2}$ per capita in Budapest. This value is much smaller than the European average, and the lack of extended green areas is one of the most significant factors in the adaptive capacity of the city. However, it is a well-known fact that urban green spaces also have pivotal role in mitigation (Csete \& Horváth, 2012). Another relevant factor concerns transportation, including the proportion of private motorized transport or the proportion of journeys by public transport, cycling or walking. Similarly to global trends, the transportation sector is one of the major contributors to greenhouse gas emissions in Budapest, since this sector is responsible for some $30-40 \%$ of total GHG emissions in the city. The ratio of modal-split is $60-40 \%$, so public transportation is used for 3 million daily journeys of total 5 million day by day (Budapest 2030 - Long-term City Development Concept, 2013). The proportion of journeys by bicycle or on foot is approximately $11 \%$ (Hungarian Central Statistical Office, 2012).

The Danube also plays a critical role in decreasing the urban heat island effect, mostly caused by built-up areas, with the existence of ventilation corridors, green spaces and water bodies, and moreover, by human emissions from the transportation and construction sector. According to Oláh (2012) ,the larger the water surface, the greater cooling - impact", moreover ,water bodies can reduce the temperature of their surroundings by even $10{ }^{\circ} \mathrm{C}$ or more". Since the average width of the Danube is 400 metres, the river is one of the most important factors in achieving climate adaptation goals and actions, moreover, it entails the threat of floods both in the present and future.

Additionally, a very significant phenomenon was examined and evaluated in a study by Ongjerth et al. (2007). According to this paper, during hot summer days the surface temperature in Central Budapest can be some $7{ }^{\circ} \mathrm{C}$ higher than surrounding areas. This difference is caused mostly by the great proportion of built-up areas, and in parallel, the lack of green areas, and furthermore, by the historical and repeated expansion of the city, and finally, by the property developments along and in the main ventilation corridors. If these facts are considered, the regulation of floodwater and the mitigation of the urban heat island effect are the key climate related challenges nowadays in Budapest.

\section{Climate change related challenges in the Carpathian basin and Budapest}

Bartholy et al. (2007) from the Department of Meteorology of the Eötvös Lóránd University of Budapest summarised the anticipated climate change forecasts for the Carpathian basin for the 2071-2100 period, based on the results of PRUDENCE project. The researchers used regional climate models to estimate the magnitude of the changes of temperature and precipitation in the region. Supporting data of these regional 
models were provided by IPCC A2 and B2 global emission scenarios. Main findings of this study are highlighting in the followings:

- $\quad$ expected increase of temperature in Carpathian basin by $2071-2100$ is between $2,5{ }^{\circ} \mathrm{C}$ and $4,8{ }^{\circ} \mathrm{C}$, depending on the season and the applied global emission scenario,

- $\quad$ expected warming in summer is between $4,0{ }^{\circ} \mathrm{C}$ and $5,3{ }^{\circ} \mathrm{C}$ in case of maximum temperature, moreover between $3,5^{\circ} \mathrm{C}$ and $4,8^{\circ} \mathrm{C}$ in case of minimum temperature,

- $\quad$ annual expected precipitation will not change significantly, but summer precipitation will likely decrease (by $24-33 \%$ according to A2 scenario and by $10-20 \%$ in case of B2), while winter precipitation is very likely to increase considerably (by $23-37 \%$ (A2) and by $20-27 \%$ (B2)),

- slight decrease of precipitation is expected in autumn, while slight increase is expected in spring,

- $\quad$ thus precipitation pattern will completely change.

Szabó (2010) summarized and identified the expected weather patterns in Budapest based on forecasts and results of five regional climate models, namely ALADIN, RACMO, RCA, HIRHAM, RegCM. Szabó studied changes of the following weather patterns firstly for 2021-2050, than for 2071-2100 period:

- number of days with frost $\left(\mathrm{T}_{\min }<0^{\circ} \mathrm{C}\right)$,

- number of days with ice $\left(\mathrm{T}_{\max }<0^{\circ} \mathrm{C}\right)$,

- $\quad$ number of hot days $\left(\mathrm{T}_{\max }>25^{\circ} \mathrm{C}\right)$,

- number of very hot days $\left(\mathrm{T}_{\max }>30^{\circ} \mathrm{C}\right)$,

- number of wet days (precipitation $>1 \mathrm{~mm}$ ),

- number of rainy days (precipitation $>5 \mathrm{~mm}$ ),

- monthly distribution of precipitation.

The main findings of this study (Szabó, 2010) were the following:

- $\quad$ the number of days with frost are expected to decrease by 2-5 days for 2021-2050 period and by 10-11 days in case of 2071-2100 period,

- the number of days with ice is very likely to decrease by $40 \%$ in case of first period, and by $60 \%$ by 2010 ,

- the number of hot days will increase by 10-12 days (mainly in June, July and August) for 2021-2050 period and by 40\% (appr. 35-40 days) until 2100,

- the increase in the number of very hot days are expected to reach 15 days by 2050 and 21 days by 2100 ,

- the number of wet and rainy days are not expected to change significantly, but similar to the findings of study of Bartholy et al., change of monthly distribution of precipitation is expected with same results to the aforementioned study.

Considering these results and findings, a number of future weather related challenges can be identified in case of Budapest. It was noted in second section that the urban heat island effect and floods threatening the city can be identified as key climate challenges facing Budapest nowadays. With respect to the regional and local climate models, it can be declared that steadily warming (mostly in summer) and changing precipitation patterns are the key issues which endanger the city's adaptive capacity.

Simultaneously with these challenges, key intervention points can be defined for coping with these changes and stopping the decrease of climate resilience. According to climaterelated studies (Walsh et al., 2011; Mills, 2006; Birkmann et al., 2010; Hunt \& Watkiss, 
2011; Szlávik \& Csete, 2012; Reckien et al., 2014), the most relevant mitigation sectors with regards to increase of resiliency are transportation, waste management, construction, energy and green areas, while the most adequate adaptation sectors are water management and green areas - as it was mentioned above, green areas are important in both adaptation and mitigation strategies -, and disaster management.

\section{Climate-oriented analysis of development and management plans of Budapest}

In this section, different actions of development and management plans of Budapest are examined from an aspect of climate mitigation and adaptation, to determine whether these plans include adaptation and/or mitigation actions regarding the previously determined local climate challenges (mitigating urban heat and protecting the city from floods) in the present and future. Three sectoral plans (Spatial Management Plan of Budapest, Sustainable Energy Action Plan of Budapest, Environmental Program of Budapest,) and two development-related documents (Integrated Urban Development Strategy of Budapest, Budapest 2030 - Long-term City Development Concept) are reviewed in this study. These plans were laid down in the near past, and all of the strategies analysed are valid, thus regulations and actions of the plans have great impact of the life of Budapest in the present and will have in the future.

It is worth declaring before the analysis that there is no comparable evaluation approach to examine these different plans, mainly because these plans do not aim to achieve the same objectives: i.e. the Spatial Management Plan does not refer to energy related issues directly, however, actions and regulations detailed in the plan have potential indirect impacts on the mentioned climate related challenges.

\subsection{Spatial Management Plan of Budapest}

This plan aims to regulate land use patterns and spatial structure, to define development trends of Budapest and technical requirements of infrastructure since 2005. It defined five main sectors having great impact on land use, and these sectors have regulations and objectives for achieving and maintaining proper spatial structure of the city. These sectors are: protection of (1) built-up and (2) natural environment, (3) transportation, (4) utility systems and (5) preservation of built heritage. Three of these have rules and objectives regarding mitigation and adaptation efforts, which are summarised in Table 1.

\subsection{Sustainable Energy Action Plan of Budapest}

Budapest joined to the Covenant of Mayors initiative in 2011 and established its own Sustainable Energy Action Plan in order to draw up the framework for reducing by $20 \%$ of the city's $\mathrm{CO}_{2}$-emission by 2020. The Covenant of Mayors - launched by the European Commission in 2009 after the adoption of the EU Climate and Energy Package - aims to support local authorities in the implementation of their sustainable energy policies. As it was mentioned above, more than two-thirds of global GHG emissions come from urban areas, thus cities play crucial role in mitigation efforts. 
Table 1. Climate-related actions and objectives of Spatial Management Plan of Budapest grouped by sectors

\begin{tabular}{|c|c|c|}
\hline Natural environment & Transport & Utility systems \\
\hline $\begin{array}{l}\text { - protection of landscape } \\
\text { features (forests and water } \\
\text { bodies) and biodiversity, } \\
\text { - development of green areas } \\
\text { and water bodies, } \\
\text { - "green-oriented" } \\
\text { development of public spaces, } \\
\text { - stopping of reduction of } \\
\text { biologically active areas, } \\
\text { - preservation of ventilation } \\
\text { corridors }\end{array}$ & $\begin{array}{l}\text { - increasing the number of } \\
\text { P+R parking lots } \\
\text { - developing traffic calming } \\
\text { measures in downtown } \\
\text { districts } \\
\text { - promoting non-motorized } \\
\text { transport modes and public } \\
\text { transport } \\
\text { - developing intermodal } \\
\text { points } \\
\text { - improving cycling and } \\
\text { walking facilities }\end{array}$ & $\begin{array}{l}\text { - designating river flood } \\
\text { control areas }\end{array}$ \\
\hline
\end{tabular}

Source: own compilation based on Spatial Management Plan of Budapest

First step for achieving reduction targets is to establish a baseline emission inventory. It quantifies the amount of $\mathrm{CO}_{2}$ emitted by different sectors in a given city during a baseline year, then allows to identify the main intervention points for reducing the amount of emitted $\mathrm{CO}_{2}$. In case of Budapest, sectors which are the major contributors to $\mathrm{CO}_{2}$ emissions are transport, energy and buildings. The second step is to develop a Sustainable Energy Action Plan (SEAP), which includes actions elaborated to achieve reduction targets. The main intervention points of SEAP determined by Budapest are:

- $\quad$ improving energy efficiency of buildings (public, private and commercial as well) supported by financial funds,

- $\quad$ using renewable energies to the local energy production,

- $\quad$ modernising the district heating system and improving the efficiency of it,

- improving energy efficiency of street lighting,

- $\quad$ promoting non-motorized transport modes.

\subsection{Environmental Program of Budapest}

The Environmental Program of Budapest was approved in 2011 by the Council, aimed to summarise actual environmental trends and condition of Budapest in order to identify the measures and activities to be able the city to become a sustainable and climate-friendly capital of the country. Program includes eight topics and 84 actions, 28 of which are in relation with climate challenges. In the beginning of the program achievable targets were determined, some of which regarding adaptation and mitigation measures:

- water saving,

- flood protection,

- $\quad$ waste management issues, such as decreasing of waste generation, improving efficiency of collection of recyclable waste,

- $\quad$ protection of natural environment and biodiversity, 
- $\quad$ reduction of city's $\mathrm{CO}_{2}$ emission by $20 \%$ by 2020 ,

- $\quad$ mitigating urban heat,

- $\quad$ reducing energy consumption,

- $\quad$ promoting non-motorized and public transportation modes,

- $\quad$ protecting green areas and brown field investments.

All topics have targets and given actions are assigned to the targets, thus efforts can be grouped clearly and accountably. The first topic refers to the climate-conscious behaviour and actions such as awareness raising campaign regarding building energy programs and heat alert are involved. The second topic aimed the positive changes in case of climate change. Existence of this topic seems a milestone in the history of urban plans of Budapest, since climate change has been emerging as a separate section in development plans of the city since then. Actions of this topic are focusing on the reduction of GHG emission in energy and transport sector, moreover on the adaptation of negative impacts of climate change. The so-called Topic " $D$ " refers to environmental quality and land use patterns of Budapest, includes five actions with regards to mitigation and adaptation. These actions are the development of non-motorised travel modes (two actions), and protecting of public green areas (three actions). Topic "E" aims to preserve biodiversity, protect environmentally endangered areas and soil. Altogether seven actions are involved in this topic and one of which (enhancing of forest areas, and protecting existing stands of trees) reflects to the climate-related issues. The sixth topic refers to water management issues, which are one of the most relevant adaptation topics not only in Budapest, but also worldwide. The topic has 16 actions, and seven of which reflects to the actual and expected climate-oriented water challenges of Budapest, such as improving the security and efficiency of drinking water supplies or issues on storm water management facing expected change of intensity of raining in the future. Measures regarding disaster management are involved in the last section with three actions of altogether eight efforts, such as improving the quality of flood protection measures, raising public awareness considering climate extremes and starting public campaign about smog and storm alerts.

\subsection{Integrated Urban Development Strategy of Budapest}

The strategy was developed in 2008 with long- and medium-term goals and seven priorities, namely: 1. dynamic economy, 2. community-centred transport, 3. liveable city, 4. environment-conscious Budapest, 5. creation of cultural value, 6. protecting Budapest, 7. partnership with the region. Three of these priorities, community-centred transport, environment-conscious and creation of cultural value priorities have mitigation and adaptation goals, while other priorities concentrate mainly on social and economic issues, in accordance with three pillars of sustainability. The priority of community-centred transport emphasizes the importance of non-motorized and public transport modes, which aim is overlapping with objectives of above mentioned development and management plans. Goals are concentrating on increase of share of journeys taken walking, by cycling and by public transport, on both from qualitative and quantitative point of view. Extension of the existing bicycle path system and the fixed-rail transportation system are key mitigation goals, and contribute to the reduction of GHG emissions. Another relevant objective is 
the development of environment-friendly transport with procurement of low emission vehicles in public transport.

Actions in environment-conscious Budapest priority concentrate on both adaptation and mitigation measures through green areas, energy and waste management sectors, and also, flood protection. Adaptation solutions such as protection and development of green areas in the city and surrounding areas are appearing in other relevant development plans, because of the key roles of green areas in connection with urban climate. Implication of complex waste management system, development of district heating system, starting awareness raising campaigns on improvement of building energy efficiency and changing to renewable energies in case of heating and cooling are key mitigation actions partly in other strategies. It can be emphasized that this strategy was developed in 2008, so that emergence of such above mentioned mitigation and adaptation actions in other strategies mainly based on measures and efforts of this development plan.

\subsection{Budapest 2030 - Long-term City Development Concept}

The long-term city development concept of Budapest is the newest and most comprehensive development of the city, established in 2013. There are two main parts of the document, in the first a broad analysis is involved, while second part refers to the development topics and actions. The main aim of the concept is to determine the sectoral development strategies in the light of economic, social and ecological situation, moreover expected economic and ecological forecasts. The document includes 17 broad topics and altogether 147 actions grouped into topics. Eight topics are in connection with climate related issues, these are: development of healthy environment conditions (topic no. 5.), climate protection and efficient energy consumption (topic no. 6.), preservation of unique character of the city (topic no. 7.), city with the Damube (topic no. 8.), efficient and balanced city structure - compact city (topic no. 9.), strengthening the brown field investments (topic no. 10.), intelligent mobility (topic no. 11.), knowledge-, skill-, and green-based economic development (topic no. 12.).

The detailed introduction of actions is not the aim of this study, but a summary of main actions and goals are involved in Table 2., grouped by topics and the type of climaterelated measure whether a given action is adaptation or mitigation effort.

This development concept is actually a collection of urban development actions from economic, social, institutional and environmental point of view. It can be noted that no. of mitigation actions overweight the no. of adaptation ones. A possible explanation to this trend is that implication of mitigation efforts need shorter time period, and the benefits are sooner coming than in the case of adaptation actions. Moreover mitigation include more precise and financially clear efforts than adaptation ones. The efficient ratio between mitigation and adaptation efforts may be approximately $50-50 \%$, such in this way the number of adaptation and mitigation actions is balanced, moreover mitigation actions entail decrease of amount of GHG emissions and at the same time increase of urban climate resilience. One of the main important improvement opportunity in the future is to balance this ratio. 
Table 2. Main mitigation and adaptation actions in the Budapest 2030 - Long-term City Development Concept, grouped by topics

\begin{tabular}{|c|c|c|c|}
\hline Topic & Actions & Mitigation & Adaptation \\
\hline \multirow{6}{*}{$\begin{array}{l}\text { Development of } \\
\text { healthy } \\
\text { environment } \\
\text { conditions }\end{array}$} & protection of green areas & $\mathbf{x}$ & $\mathbf{x}$ \\
\hline & increase of intensity of green covered areas & $\mathbf{x}$ & $\mathbf{x}$ \\
\hline & reduction of GHG emissions & $\mathbf{x}$ & \\
\hline & reduction of amount of generated waste & $\mathbf{x}$ & \\
\hline & utilisation of rainwater & & $\mathbf{x}$ \\
\hline & development of flood protection measures & & $\mathbf{x}$ \\
\hline \multirow{7}{*}{$\begin{array}{l}\text { Climate protection } \\
\text { and efficient energy } \\
\text { consumption }\end{array}$} & mitigating urban heat island effect & & $\mathbf{x}$ \\
\hline & development of energy efficient and low emission buildings & $\mathbf{x}$ & \\
\hline & changing to renewable energy sources & $\mathbf{x}$ & \\
\hline & development of smart grid and smart metering & $\mathbf{x}$ & \\
\hline & development of district heating system & $\mathbf{x}$ & \\
\hline & $\begin{array}{l}\text { designing a walkable and cyclable city with urban } \\
\text { planning }\end{array}$ & $\mathbf{x}$ & \\
\hline & procurement of low emission vehicles in public transport & $\mathbf{x}$ & \\
\hline \multirow{2}{*}{$\begin{array}{l}\text { Preservation of } \\
\text { unique character of } \\
\text { the city }\end{array}$} & ensuring ecological connections & & $\mathbf{x}$ \\
\hline & preservation of natural wealth & & $\mathbf{x}$ \\
\hline \multirow{2}{*}{$\begin{array}{l}\text { City with the } \\
\text { Danube }\end{array}$} & utilisation of the value of the Danube & & $\mathbf{x}$ \\
\hline & walking and cycling corridors along the Danube & $\mathbf{x}$ & \\
\hline \multirow{4}{*}{$\begin{array}{l}\text { Efficient and } \\
\text { balanced city } \\
\text { structure - compact } \\
\text { city }\end{array}$} & designing sustainable and compact city structure & $\mathbf{x}$ & $\mathbf{x}$ \\
\hline & $\begin{array}{l}\text { regulating land use patterns in order to achieve compact } \\
\text { spatial structure }\end{array}$ & $\mathbf{x}$ & $\mathbf{x}$ \\
\hline & upgrading green covered areas & $\mathbf{x}$ & $\mathbf{x}$ \\
\hline & prevention of urban sprawl & $\mathbf{x}$ & $\mathbf{x}$ \\
\hline $\begin{array}{l}\text { Strengthening of the } \\
\text { brownfield } \\
\text { investments }\end{array}$ & $\begin{array}{l}\text { strengthening of the brownfield investments instead of } \\
\text { greenfield development }\end{array}$ & & $\mathbf{x}$ \\
\hline \multirow{3}{*}{ Intelligent mobility } & $\begin{array}{l}\text { increasing share of travels by walking, cycling with urban } \\
\text { planning solutions }\end{array}$ & $\mathbf{x}$ & \\
\hline & traffic calming in downtown districts & $\mathbf{x}$ & \\
\hline & development of fixed-rail transportation system & $\mathbf{x}$ & \\
\hline $\begin{array}{l}\text { Knowledge-, skill-, } \\
\text { and green-based } \\
\text { economic } \\
\text { development }\end{array}$ & embedding of the basis of green economy & $\mathbf{x}$ & $\mathbf{x}$ \\
\hline
\end{tabular}

Source: own compilation based on Budapest 2030 - Long-term City Development Concept 


\section{Summary and conclusion}

The current urban development and management plans of Budapest clearly define the main challenges of climate change and intervention points not from a social, ecological and economic point of view, but also climate related issues are involved with these trends. Different types of plans might be distinguished in the sense of main aims, thus development and sectoral or management plans can be evaluated from divergent point of view. Analysis of plans of Budapest showed that there are some overlapping actions in the strategies, but it can be noted that these actions actually refer to the main climate challenges of Budapest in the present and the future. As it was defined above, these challenges are the changing precipitation patterns with heavier rainfalls and steadily warming. Urban strategies of Budapest include main aims to decrease these challenges, consequently it may be noted that the city may prepare to the main climate changes emerging in the region. It is worth emphasizing that definition of expected problems and developing strategies responding to them is only one side of the coin. The second crucial step is the implementation of actions; moreover systematic revision of forecasts is crucial. Failing at this, Budapest may well lose its adaptive capacity and the city might be more vulnerable to the climate change related challenges. Since Budapest is the hub of the Hungarian economy, and since more than 1.7 million people live here, the preparations for climatic changes are a key step in a way of being prosperous city and the hub of region. Finally, there is often a lack of defining time frames and responsibilities in strategies, such this step is a crucial and necessary improvement opportunity for enhancing efficiency of strategies.

The main conclusion of this study in the sense of different development plans is that Budapest has the potential of being climate resilient city, because main climate challenges are properly defined and related strategies are developed.

However, there are two important opportunities in connection with the plans. Firstly, there is a lack of comprehensive climate strategy in Budapest, which may distinguish climate related actions and measures from other sectors, moreover climate forecasts, targets and actions can be summarised in one document together with time frames and responsibilities. These latter two offer a pivotal opportunity for improving the city's development plans not only in case of climate strategy but also in case of other sectoral and management plans. It should be underlined that implication of actions has crucial role in achieving objectives, hence development of effective monitoring system will be necessary in the future climate plan of Budapest. Secondly, the establishment of the Climate Council of Budapest should ensure stakeholder involvement and knowledge transfer in decision-making processes, by involving NGOs, experts from different scientific fields and key players from the public sector.

\section{References}

Bartholy, J., Pongrácz, R., Gelybó, Gy. (2007). Regional climate change expected in Hungary for 2071-2100. Applied Ecology and Environmental Research, 5, 1-17.

Birkmann, J., Garschagen, M., Kraas, F., Quang, N. (2010). Adaptive urban governance: new challenges for the second generation of urban adaptation strategies to climate change. Sustainability Science, 5, 185-206. 
Budapest 2030 - Long-term City Development Concept. (2013). (In Hungarian)

http://budapest.hu/Documents/varosfejlesztesi koncepcio_bp2030/Budapest 2030 varosfejlesz tesi koncepcio.pdf

Accessed: 10.05.2014.

Csete, M., \& Horváth, L. (2012). Sustainability and green development in urban policies and strategies. Applied Ecology and Environmental Research, 10, 185-194.

Csete, M., Pálvölgyi, T., Szendrő, G. (2013). Assessment of Climate Change Vulnerability of Tourism in Hungary. Regional Environmental Change, 13, 1043-1057.

Dhakal, S. (2010). GHG emissions from urbanization and opportunities for urban carbon mitigation.

Current Opinion in Environmental Sustainability, 2, 277-283.

Environmental Program of Budapest. (2011). (In Hungarian) http://budapest.hu/Documents/FKP 4\%201 111119.pdf Accessed: 10.05.2014.

Global Institute. (2011). Urban world: Mapping the economic power of cities. http://www.mckinsey.com/ /media/McKinsey/dotcom/Insights $\% 20$ and $\% 20$ pubs/MGI/Resea rch/Urbanization/Urban $\% 20$ world $\% 20$ mapping $\% 20$ economic $\% 20$ power $\% 20$ of $\% 20$ cities/MGI urban world mapping economic power of cities full report.ashx Accessed: 10.05.2014.

Grimm, N. B., Faeth, S. H., Golubiewski, N. E., Redman, C. L., Wu, J., Bai, X., et al. (2008). Global Change and the Ecology of Cities. Science, 319, 756-760.

Han, J., Fontanos, P., Fukushi, K., Herath, S., Heeren, N., Naso, V. et al. (2012). Innovation for sustainability: toward a sustainable urban future in industrialized cities. Sustainability Science, 7, 91100.

Hungarian Central Statistical Office. (2012). Statistical Yearbook of Budapest, 2011.

Hunt, A., \& Watkiss, P. (2011). Climate change impacts and adaptation in cities: a review of the literature. Climatic Change, 104, 13-49.

Integrated Urban Development Strategy of Budapest. (2008). (In Hungarian) http://budapest.hu/Documents/integralt_varosfejlesztesi_strategia.pdf Accessed: 10.05.2014.

International Energy Agency. (2008). WEO: World Energy Outlook 2008. http://www.iea.org/publications/freepublications/publication/weo2008.pdf Accessed: 05.04.2014.

LeQuere, C., Raupach, M. R., Canadell, J. G., Marland, G., Bopp, L., Ciais, P., et al. (2009). Trends in the sources and sinks of carbon dioxide. Nature Geoscience, 2, 831-836.

Mills, G. (2006). Progress toward sustainable settlements: a role for urban climatology. Theoretical and Applied Climatology, 84, 69-76.

Oláh, A. B. (2012). The possibilities of decreasing the urban heat island. Applied Ecology and Environmental Research, 10, 173-183.

O’Meara, Molly. (1999) Reinventing Cities for People and the Planet. Worldwatch, Washington DC.

Ongjerth, R., Gábor, P. and Jombach, S. (2007). Connection between urban heat island and intensity of green covered areas. Studio Metropolitana, Budapest. (In Hungarian)

Reckien, D., Flacke, J., Dawson, R. J., Heidrich, O., Olazabal, M., Foley, A., et al. (2014). Climate change response in Europe: what's the reality? Analysis of adaptation and mitigation plans from 200 urban areas in 11 countries. Climatic Change, 122, 331-340.

Spatial Management Plan of Budapest. (2005). (In Hungarian) http://budapest.hu/Documents/TSZT.pdf Accessed: 10.05.2014.

Sustainable Energy Action Plan of Budapest. (2011). (In Hungarian) http://budapest.hu/Documents/20111118 energia akcioterv SEAP.docx Accessed: 10.05.2014.

Szabó, D. (2010). Impact of climate change on supply of tourism sector in Hungary. Diploma thesis, Budapest. (In Hungarian)

Szlávik, J., Csete, M. (2012). Climate and Energy Policy in Hungary. Energies, 5, 494-517.

UN. (2010). World Urbanization Prospects: The 2009 Revision. United Nations Department of 
Economic and Social Affairs, Population Division, New York.

UN. (2012).World Urbanization Prospects: The 2011 Revision. United Nations Department of Economic and Social Affairs, Population Division, New York.

Walsh, C. L., Dawson, R. J., Barr, S. L., Batty, M., Bristow, A. L., Sebastian, C. et al. (2011).

Assessment of climate change mitigation and adaptation in cities. Urban Design and Planning, 164, 75-84. 